\title{
Acadiensis
}

Journal of the History of the Atlantic Region

Revue d'histoire de la région Atlantique

ACADIENSIS

\section{Nuclear Power Decision-Making in New Brunswick, 1971-1975}

\section{Andrew G. Secord}

Volume 49, numéro 1, printemps 2020

URI : https://id.erudit.org/iderudit/1072252ar

Aller au sommaire du numéro

\section{Éditeur(s)}

Department of History at the University of New Brunswick

ISSN

0044-5851 (imprimé)

1712-7432 (numérique)

Découvrir la revue

Citer cet article

Secord, A. (2020). Nuclear Power Decision-Making in New Brunswick, 1971-1975. Acadiensis, 49(1), 123-150.

\section{Résumé de l'article}

Cet article explore les origines du réacteur nucléaire de Point Lepreau, dans le Sud du Nouveau-Brunswick, et s'intéresse particulièrement aux stratégies d'entreprise des deux sociétés d’État les plus directement concernées : la Commission d'Énergie électrique du Nouveau-Brunswick (CEENB) et Énergie atomique du Canada limitée (EACL). Bien que leur décision en faveur du nucléaire ait été de plus en plus contestée au sein de l'État fédéral, les dirigeants de la CEENB déployèrent des efforts vigoureux pour maintenir leur programme nucléaire et, ce faisant, prirent des risques supplémentaires. Au moment de la décision finale, en 1974, ils allèrent de l'avant en dépit des augmentations imprévues des coûts de construction estimatifs et de l'absence de partenaires potentiels. 


\title{
Nuclear Power Decision-Making in New Brunswick, 1971-1975
}

\author{
ANDREW G. SECORD
}

\begin{abstract}
Cet article explore les origines du réacteur nucléaire de Point Lepreau, dans le Sud du Nouveau-Brunswick, et s'intéresse particulièrement aux stratégies d'entreprise des deux sociétés d'État les plus directement concernées : la Commission d'Énergie électrique du Nouveau-Brunswick (CEENB) et Énergie atomique du Canada limitée (EACL). Bien que leur décision en faveur du nucléaire ait été de plus en plus contestée au sein de l'État fédéral, les dirigeants de la CEENB déployèrent des efforts vigoureux pour maintenir leur programme nucléaire et, ce faisant, prirent des risques supplémentaires. Au moment de la décision finale, en 1974, ils allèrent de l'avant en dépit des augmentations imprévues des coûts de construction estimatifs et de l'absence de partenaires potentiels.
\end{abstract}

This article explores the origins of the Point Lepreau nuclear reactor in southern New Brunswick, with a focus on the corporate strategies of the two state enterprises most directly involved: the New Brunswick Electric Power Commission (NBEPC) and Atomic Energy of Canada Limited ( $A E C L$ ). Although their nuclear decision was increasingly challenged from within the federal state, NBEPC officials worked aggressively to maintain their nuclear timeline and took on additional risks in the process. At the final decision point in 1974, they proceeded notwithstanding unforeseen increases in estimated construction costs and without potential partners.

AT A COMMUNITY MEETING ON 25 JULY 1974 at the Dipper Harbour Church Hall, three-quarters of the 200 people in attendance stood to express their opposition to the proposed Lepreau nuclear reactor. When they asked the representative of New Brunswick Electric Power Commission (NBEPC) at the meeting to explain why they planned to build the reactor in their community, he limited his reply to the local factors that would reduce the costs of the nuclear project: access to cooling water from the Bay of Fundy and proximity to transmission lines. ${ }^{1}$ Unsatisfied with such simplistic explanations, many demanded the project be cancelled while others worked for a delay and

\footnotetext{
1 "Shore Residents Don't Want Lepreau Nuclear Power Plant," Telegraph Journal (Saint John), 27 July 1974.
} 
public inquiry. ${ }^{2}$ In her history of the local communities - Chance Harbour, Dipper Harbour, and Maces Bay - Ethel Thompson recounts: "The news that a scientific wonder, and industrial giant with a continuous threatening wastecontrol problem, was scheduled for placement in the centre of the traditional communities was received with mixed feelings." 3 This article explores the origins of the Point Lepreau nuclear reactor utilizing the archival records of the key organizations involved - the NBEPC and Atomic Energy of Canada Limited (AECL) - records that members of the local communities could not access at the time.

Academic research into nuclear power decision-making in Canada during the 1970s has focused on Ontario and Quebec. ${ }^{4}$ The few academic references to the Lepreau decision speculate that the reactor was chosen by the New Brunswick government in response to rising international oil prices, energy security problems, and/or for economic development reasons. ${ }^{5}$ Such explanations view the nuclear decision as a response to challenges external to the electricity sector. In contrast, this research situates the decision in the institutional context and growth dynamic of the public power sector in New Brunswick. Consequently, the research takes a state-centric approach and focuses on the policy formation process within the federal and provincial states - notably within NBEPC. ${ }^{6}$ This research is also informed by the literature on organizational decision-making, especially the type of organizational path dependency where managers manifest "lock-in" behaviour and continue with major investments in spite of changed circumstances that nullify their economic viability. The phenomenon is not uncommon among industries, such as nuclear power, with exceptionally long planning and construction phases.? Daniel Kahneman and Amos Tversky theorize that as sunk costs

2 "Reactions Vary on Nuclear Plant," Telegraph Journal, 20 July 1974.

3 Ethel Anne Thompson, The Tides of Discipline (St. Stephen, NB: Print'N Press Ltd., 1978), 96.

4 See, for example, Robert Bothwell, Nucleus: The History of Atomic Energy of Canada Limited (Toronto: University of Toronto Press, 1988) and Mahdi Khelfaoui, "Le nucléaire dans la stratégie énergétique du Québec, 1963-2012," Scientia Canadensis 37, no. 1-2 (2014): 105-32.

5 See Bothwell, Nucleus, 423 and Duane Bratt, Canada, the Provinces, and the Global Nuclear Revival (Montreal and Kingston: McGill-Queen's University Press, 2012), 173.

6 For an overview of the productivity of the state-centric approach, see Theda Skocpol, "Bringing the Sate Back In: Retrospect and Prospect," Scandinavian Political Studies 31, no. 2 (May 2008): 109-24.

7 Werner F.M. De Bondt and Anil K. Makhija, "Throwing Good Money after Bad? Nuclear Power Plant Investment Decisions and the Relevance of Sunk Costs," Journal of Economic Behavior and Organization 10, no. 2 (September 1988): 173-99. 
increase in magnitude then managers are willing to take on higher levels of risk to protect their previous investments. ${ }^{8}$ Helga Drummond, in her survey of the organizational behaviour literature on institutional commitment to increasingly uneconomic megaprojects, provided an overview of the individual, institutional, and social mechanisms involved. Based on a survey of empirical studies, she included among causal mechanisms the psychological tendency to bias information to defend previous personal decisions, unconscious attachment to "pet" projects, and cultural biases against admitting major errors. ${ }^{9}$

In the late 1960s NBEPC executives focused their planning on creating the pre-conditions for a nuclear path, without which they would be restricted to oilfired generation or long-term imports from Hydro-Québec. Because they were too small to risk a capital-intensive nuclear reactor on their own, they sought shared ownership with other, larger, utilities that they could only have if they developed high-voltage interconnections with New England. Consequently, they dedicated their resources to building high-voltage interconnections and exchanges with New England utilities to open up the US market for nuclear power from New Brunswick. The New England demand for Canadian nuclear power, however, never materialized and NBEPC managers were forced to shift their focus back to the smaller Maritime market. When their attempts at risksharing with other Maritime utilities also failed, NBEPC mangers decided to proceed with the nuclear option on their own. In the process, they worked with their pro-nuclear network within the federal state to avoid a federal economic evaluation and a complete environmental review as conditions for federal assistance.

Analysis of these inter-agency networks requires extensive documentary evidence. This article utilizes the archival material of several federal and provincial departments and agencies available through Library and Archives Canada and the Provincial Archives of New Brunswick as well as documents accessed through the New Brunswick Right to Information Act and the federal Access to Information and Privacy Act.

8 Daniel Kahneman and Amos Tversky, "Prospect Theory: An Analysis of Decision Under Risk," Econometrica 47, no. 2 (March 1979): 263-91.

9 Helga Drummond, "Megaproject Escalation of Commitment: An Update and Appraisal," in The Oxford Handbook of Megaproject Management, ed. Bent Flyvbjerg (Oxford: Oxford University Press, 2017): 194-216. 


\section{Nuclear power for export from a New Brunswick platform, April 1971-September 1972}

The Canadian nuclear industry was dominated by the federal Crown corporation AECL, which by the late 1960 s was the principal source of pure research, reactor design, and construction of experimental reactors in Canada. ${ }^{10}$ What was originally designed as a small reactor program to produce plutonium for American nuclear weapons ${ }^{11}$ evolved into AECL's distinctive commercial heavy water CANDU design, which AECL hoped could compete in domestic and international markets. ${ }^{12}$ AECL's first commercial customer, Ontario Hydro, committed to four CANDU reactors (508 megawatts each) at Pickering in 1968 with expected completions between 1971 and 1973. Officials at AECL, the National Energy Board, and the federal Department of Energy and Resources Management were all strong advocates of the Canadian reactor design. Typical of this optimism was a 1968 article in the Engineering Journal of the Canadian Engineering Institute in which the author predicted that almost all new electrical energy generation after 1980 in Ontario, Quebec, and the Maritimes would be nuclear. ${ }^{13}$ For AECL an expanding Canadian nuclear industry also depended on success in the international reactor market, which was dominated by global multinationals such as Westinghouse and General Electric. The most lucrative export market for AECL was the United States, and NBEPC took on a special role in AECL's marketing strategy - a role consistent with NBEPC's focus on the New England market.

10 For a listing of the public and private design, component, and government agencies involved in the nuclear industry in Canada in the early 1970s, see Nuclear Engineering International 19, no. 217 (June 1974): 500-3.

11 The role of $A E C L$ in supplying plutonium to the American nuclear weapons program is well documented; see, for example, Duane Bratt, "Canada's Nuclear Schizophrenia," Bulletin of the Atomic Scientists 58, no. 2 (March/April 2002): 45-50. The economic justification for AECL's first reactor, NRU, was based in part on selling plutonium for about $\$ 5,000$ per ounce to the American weapons program in the 1950 s.

12 Various sources document the history of $A E C L$ and their marketing strategies by the late 1960s. See Robert Bothwell, Nucleus; Duane Bratt, The Politics of CANDU Exports (Toronto: University of Toronto Press, 2006); Ron Finch, Exporting Danger: A History of the Canadian Nuclear Energy Export Program (Montreal: Black Rose Books, 1986); Fred Knelman, Nuclear Energy (Edmonton: Hurtig, 1976); and Laurel Sefton MacDowell, "Nuclear Power," in Powering Up Canada, ed. R.W. Sandwell (Montreal and Kingston: McGill-Queen's University Press, 2016), 329-52. The CANDU (Canada Deuterium Uranium) design used natural uranium fuel with heavy-water moderation and cooling and a pressure tube core (calandria) rather than the enriched-fuel, pressure-vessel design of the more common American and European light-water reactors.

13 H.B. Merlin, "The CANDU Reactor and Canada's Economy," Engineering Journal 51, no. 10 (October 1968): 19-27. 
During the 1950 s the provincially owned NBEPC established a nearcomplete public monopoly of the generation, transmission, and distribution of electricity in New Brunswick, with a public mandate to exploit the province's hydroelectric resources arising from a power-for-industry strategy. The St. John River was transformed by a series of hydroelectric dams into an efficient hydro generating system supported by thermal investments in coal and oil-fired generation to complement hydro's uneven water-flow characteristics. In the process, electricity rates fell in real terms, rural electrification was completed, major inward investments in resource-processing industries (especially pulp and paper and base metal processing) were supplied with large quantities of electricity, and successive governments gained political benefits from the short-term construction jobs and spin-offs for local business. ${ }^{14}$ In 1967, NBEPC managers, confronted with the exhaustion of profitable hydro sites and slower rates of growth in the resource sector, employed international consultants to assist in constructing an alternative organizational growth strategy for NBEPC. The result was a new export-led strategy, to be driven by electricity exports to the United States. It was hoped that NBEPC could overcome the constraints of their own small provincial market by building large generating units in New Brunswick to serve the New England market.

Between 1968 and 1971, NBEPC focused on developing high-voltage transmission interconnections, corresponding agreements, and sales contracts to facilitate export sales to New England utilities. Its first major export package involved sales to New England based on re-selling Hydro-Québec purchases between 1970 and 1975, in the process generating over $\$ 5$ million in profits. The second major package involved exporting 400 megawatts yearly from 1976 to 1986 to a consortium of New England utilities from a new 900-megawatt, oilfired generator at Coleson Cove, expected to generate $\$ 80$ million in profits to NBEPC. Since NBEPC's sales revenue in 1970 was $\$ 48$ million, the new export strategy was considered a tremendous success by NBEPC managers and provincial politicians given the magnitude of the growth in sales, corporate profits, short-term job creation, and business opportunities. As NBEPC managers developed the export market, they began to talk more about their

14 For an exploration of the origins of the power-for-industry strategy, see R.A. Young, "Planning for Power: The New Brunswick Electric Power Commission in the 1950s," Acadiensis XII, no. 1 (Autumn 1982): 73-99; James L. Kenny and Andrew Secord, "Public Power for Industry: A Re-examination of the New Brunswick Case, 1940-1960," Acadiensis XXX, no. 2 (Spring 2001): 84-108; and James L. Kenny and Andrew C. Secord, "Engineering Modernity: Hydro-Electric Development in New Brunswick, 1945-1970," Acadiensis XXXIX, no. 1 (Winter/Spring 2010): 3-26. 
strategic geographical position as a basis to generate growth through exports and less about their power to attract industry to New Brunswick. ${ }^{15}$

NBEPC managers regarded oil-fired exports as only an interim supply choice until the CANDU nuclear system was at a mature stage of commercialization, capable of serving from New Brunswick both provincial demand and the New England market. In testimony before the National Energy Board in 1969 and 1972, NBEPC witnesses emphasized the connection between nuclear power and high-voltage interconnections "to permit installations in the Canadian system of extremely large units, such as are involved in the nuclear developments without which power costs in the Atlantic area will never be reduced." ${ }^{16}$ Senior management of NBEPC had been actively involved in the development of the Canadian nuclear industry as members of the AECL board of directors since the early 1960s and in 1968 the general manager of NBEPC joined the board of directors of the Canadian Nuclear Association, the principal industry association and advocate for nuclear interests in Canada. ${ }^{17}$

With the completion of the interconnections with New England, NBEPC shifted its planning almost exclusively to nuclear power. At meetings in Toronto in April 1971, AECL Vice-President John Foster proposed a 500-megawatt reactor for NBEPC similar to the Pickering units in Ontario. ${ }^{18}$ Senior executives of NBEPC and AECL met again in Fredericton on 22 July. There was shared optimism that NBEPC's current platform for exporting thermal power to New England could be doubled or tripled in size to serve what they viewed as a virtually unlimited export market for nuclear power. The meeting concluded with an agreement that AECL would develop cost estimates for the reactors, NBEPC would proceed with negotiations with American utilities, and both agencies would work jointly in preparing a submission to

15 This synopsis of the origins of NBEPC's export strategy is based on Andrew G. Secord, "NB Power 1967-72: Constructing the Export Dream," Journal of New Brunswick Studies 10 (Fall 2018): 3-20.

16 See the testimony of Frank MacLoon in 1972, repeating previous testimony of 1969, in transcript of National Energy Board Hearings of 18 April 1972 held in Fredericton, NEB Order No. EH-2-72, K9 C16h Ap. National Energy Board Library, Calgary.

17 Minutes of CNA board meetings for this period can be found in file 3-333 CNA, NB Power Central Records (Fredericton). In 1973 A.J. O'Connor, General Manager of NBEPC, was elected president of the Canadian Nuclear Association.

18 A summary of these discussions can be found in J.S. Foster, Vice-President Power Projects, AECL, to A.J. O'Connor, General Manager, NBEPC, 22 April 1971, file 3-333, Atomic Power 1971, NB Power Central Records. 
the federal government for financial assistance. ${ }^{19}$ Between July and December 1971, AECL and NBEPC managers constructed a proposal that included not only conventional financial assistance but also federal risk coverage and early regulatory approvals for two 600-megawatt CANDU reactors, with 1,000 megawatts dedicated for export over a 15-to-20 year period..$^{20}$ By December 1971, senior executives of AECL and NBEPC were discussing their common interests and the need for common action in dealing with other federal government

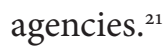

On 6 December 1971, NBEPC's senior officials presented their nuclear export proposal, "An Export Power Program for New Brunswick with Nuclear Power," to senior officials of the federal departments of Energy, Mines, and Resources (EMR); Finance; Industry, Trade, and Commerce; Transport; Regional Economic Expansion; External Affairs; and Environment as well as the National Energy Board and AECL. NBEPC argued that it was uniquely positioned among Canadian utilities as a base to export CANDU nuclear electricity to the American market. For AECL officials, successful CANDU energy exports to the American market could establish the competitiveness of the CANDU design for future export sales to the United States and enhance the status of the CANDU technology for future international sales. Additionally, they argued that it could open up the possibility of locating CANDU reactors in the United States. For NBEPC, it would accelerate their transition to nuclear power. ${ }^{22}$ The proposal also identified the basis upon which the CANDU exports could be competitive in the New England market. These included NBEPC's lack of corporate income taxation, lower rates of taxation on property and assets,

19 Minutes of Meeting AECL and NBEPC, Fredericton, 22 July 1971, Lepreau Records, 8700000, General Project, folder 1, NB Power Central Records.

20 As part of their market research, in the summer of 1971 NBEPC solicited proposals from Westinghouse and General Electric for an American reactor for New Brunswick. The purpose of the process, as the general manager of NBEPC pointed out to Boston Edison representatives in January 1972, was to gain commercial information on their competitors. See Notes on Meeting with Vice-President of Boston Edison, 19 January 1972, Lepreau Records, 87-00000, folder 2, NB Power Central Records.

21 See, for example, General Manager, Nuclear Power Marketing, AECL to General Manager of NBEPC, 10 November 1971, Lepreau Records, 87-00000, folder 2, NB Power Central Records and "Notes on Nuclear Power Meeting AECL and Canatom, Dec. 13 and 14, 1971," 30 December 1971, file 3-333, Atomic, NB Power Central Records.

22 "An Export Power Program for New Brunswick with Nuclear Power," 6 December 1971, Department of Finance Records, RG 19, 5362, 3954, L599-1, Library and Archives Canada (LAC), Ottawa. 
and fewer regulatory delays than in the U.S. ${ }^{23}$ Moreover, American utilities were faced with continual and effective public opposition to nuclear reactors in the northeastern US, which NBEPC could avoid with early regulatory approvals from the National Energy Board, the Atomic Energy Control Board (AECB), and the Department of Environment (DOE).

The submission clarified the challenges facing NBEPC if it was to invest in nuclear power for the export market, including negotiating long-term contracts with New England utilities as well as receiving expeditious regulatory approvals from federal agencies, federal guaranteed loans to cover all or part of NBEPC's borrowing requirements, and federal government coverage of the risks of construction cost overruns and poor operating performance of the nuclear reactor. NBEPC senior executives argued that AECL should finance, design, and construct the plant, and then sell the site to NBEPC after five years of successful operation. Alternatively, they would accept the federal government providing sufficient financial participation and risk coverage to ensure that the nuclear plant would be no more expensive (or risky) than an oil-fired unit. They were specifically concerned with the "abnormal risks related to cost and performance" of nuclear technology, which was "not entirely proven." ${ }^{24}$ This, they argued, was especially important as NBEPC's entire generating capacity in 1971 was less than the 1,200 megawatts of the proposed nuclear project.

In response to NBEPC's request for financial assistance, the federal government established an interdepartmental committee chaired by EMR's assistant deputy minister for Energy Development - other members included representatives from Finance; Industry, Trade, and Commerce; and AECL - to recommend a federal response to NBEPC's request. ${ }^{25}$ The resulting Memorandum to Cabinet (10 March 1972) did not recommend any assistance to NBEPC to cover its exceptional risks in the areas of uncertain construction costs and reactor operating performance. There was no reference to AECL owning the reactor for five years or the federal government ensuring that the reactor would not expose NBEPC to any risks greater than an oil-fired

23 For example, local taxes in Massachusetts were as high as 16 per cent of revenue for some utilities; see "An Export Power Program for New Brunswick with Nuclear Power," pp. 10-11, Department of Finance Records, RG 19, 5362, 3954, L599-1, LAC.

24 "An Export Power Program for New Brunswick with Nuclear Power," p. 15, Department of Finance Records, RG 19, 5362, 3954, L599-1, LAC.

25 J.L. Gray, President, AECL to Jack Austin, Deputy Minister, Energy, Mines and Resources, 31 January 1972, EMR Records, Lepreau Nuclear Power Station, X-086-30/4-1, LAC. 
alternative. ${ }^{26}$ The Memorandum to Cabinet did recommend a federal loan for 50 per cent of the estimated construction costs (to be capped at a predetermined level), with the loan guaranteed by the province of New Brunswick and not the federal government. ${ }^{27}$ Additionally, the choice of the site was to be the subject of future discussions regarding the federal government's broader employment and industrial considerations. ${ }^{28}$ EMR officials worked closely with AECL and NBEPC to maximize federal assistance, but they were unable to overcome resistance from the federal Department of Finance to AECL owning the plant, unwilling to take on the risk of capital cost overruns and poor operating performance of a provincially owned electrical generator, and were doubtful that NBEPC could manage its own financial exposure. ${ }^{29}$ Typical of the analysis by the Department of Finance officials was the memo of Myles B. Foster on 29 March 1972, in which he concluded: “The corporation is a small, high cost (11.75) utility with barely enough cash flow to finance its present debt. Its acquisition of two large nuclear reactors is the equivalent of a Volkswagen family acquiring a Cadillac as a second car." ${ }^{30}$ Further, by the end of April, Finance officials concluded that the project was not competitive in the US market, and that NBEPC was not strong enough financially to carry out the project. ${ }^{31}$ Adding to Finance's skepticism was the economic analysis that the federal Treasury Board Secretariat was completing on the economics

26 "Memorandum to Cabinet - Federal Support for a Nuclear Power Station in New Brunswick," 10 March 1972, EMR Records, Lepreau Nuclear Power Station, X-086-30/4-1, LAC.

27 In the proposed agreement, the federal government would borrow the funds and provide them to New Brunswick at the federal borrowing rate while New Brunswick was required to guarantee the loans. See Memorandum from R.N. Spalding to Myles B. Foster, Subject: Preliminary Analysis of New Brunswick Electric Power Commission, 14 June 1972, Department of Finance Records, RC 19, vol. 5362, file 3954-L599-3, pt. 3, Lepreau-Financing, LAC.

28 "The Cabinet Committee on Government Operations - Record of Committee Decision Meeting, Meeting of March 14, 1972 Federal Support for Nuclear Power Stations in New Brunswick and Quebec," 14 March 1972, EMR Records, X085-3, vol. 2, LAC.

29 S.S. Reisman to Jack Austin, Deputy Minister, Finance, 7 February 1972, RG 19, vol. 5362 , file 3954/L599-3-pt. 1, LAC; "Memo from R.A. Fleming to Oestreicher, Thom Subject: New Brunswick Nuclear Power Project Meeting - February 4," 7 February 1972, Department of Finance Records, RG 19, vol. 5362, file 3954/L599-3, pt. 1, LAC.

30 M. Foster to D.M. Jacobs, 29 March 1972, Dept. of Finance Records, RG 19, vol. 3954/L599-3, pt. 2, LAC. NBEPC's average kilowatt hour cost was 11.75 mills versus Ontario Hydro's cost of 7.15 mills. A mill is one-tenth of a cent. See Myles Foster to R.N. Spalding, 14 April 1972, Department of Finance Records, RG 19, vol. 3954/L599-3, pt. 1, LAC.

31 Memorandum from R.A. Flemming to S. Reisman, Subject: New Brunswick Nuclear Power Project, 28 April 1972, Department of Finance Records, RG 19, vol. 5362, file 3954/ L599-3, pt. 2, LAC. 
of nuclear power in Canada. Specifically, Treasury Board officials challenged the assumption that rising fossil fuel costs would drive the demand for nuclear reactors in Canada as the relatively greater capital costs of nuclear power would likely escalate faster than fossil fuel prices. ${ }^{32}$

Further problems arose when the general manager of NBEPC finally met for serious discussions with New England utility executives (Central Maine Power, New England Electrical System, and Central Vermont Public Service) in August 1972, where the response was overwhelmingly negative..$^{33}$ Across New England, utilities were committing to US nuclear projects that, although over budget, were beginning to overcome regulatory interventions. The export strategy was confronted with what the general manager of NBEPC recorded in his meeting notes as "a developing sentiment for the US utilities to be self-sufficient." ${ }^{34}$

Although the export platform initiative failed in 1972, it was an important time for the construction of social relations among pro-nuclear agencies within the provincial and federal state. Especially relevant were the developing relations among a network of officials within NBEPC, EMR, and AECL, and their willingness and capacity to act strategically. The nuclear network had expanded from AECL providing assistance to NBEPC managers in preparing their brief in December 1971 to the point where they were developing common tactics in 1972 negotiations with other federal agencies, ${ }^{35}$ sharing early drafts of provincial political correspondence with federal officials, and briefing each other before meetings with federal and provincial politicians. ${ }^{36} \mathrm{AECL}$ and NBEPC also shared information pertaining to the environmental opposition to nuclear power, including lists of writers to local newspapers, copies of their

32 "Efficiency Perspectives on Current Proposals for Canadian Nuclear Power Development," Planning Branch, Treasury Board Secretariat, May 1972, Deptartment of Finance Records RC 19, vol. 5358, file 3940-10, pt. 1, 1972-1973 Nuclear Power - Study of Nuclear Power Program, LAC. The conflict between the Treasury Board Secretariat and AECL over the economics of CANDU extended into 1973. See, for example, "Report Summary: Some Additional Comments on T.B.S. Perspective on the Canadian Nuclear Power Program," 8 March 1973, Department of Finance Records RG 19, vol. 5357, file 3940-02, pt. 1, Nuclear Power - Policy Dev. 1967-73, LAC.

33 The dates of eight such meetings are recorded in "Chronological Listing of the Nuclear Power Project," Lepreau Records, 87-00000, folder 1, NB Power Central Records.

34 "Notes of Meeting with New England Utility Representatives, August 22, 23, and 24, 1972," 1 September 1972, Lepreau Records, 87-00000, folder 4, NB Power Central Records.

35 "Notes on Nuclear Power Meeting AECL and CANATOM," 30 December 1971, file 100714566, NB Power Central Records.

36 A.J. O'Connor to G.M. MacNabb, 9 February 1972, file 3-333, Atomic 1972, NB Power Central Records. 
responses, and analyses of the strengths of the environmental movement. They coordinated their public responses and worked closely with the Canadian Nuclear Association in their public relations campaigns in New Brunswick. ${ }^{37}$

\section{Heavy water/nuclear complex, March 1973-October 1973}

In March 1973, AECL approached NBEPC suggesting they together compete with Quebec, Saskatchewan, and Alberta as a site for AECL's proposed 8oo-ton-per-year heavy water plant in combination with a New Brunswick 600-megawatt nuclear reactor that would supply 200 megawatts of process steam to the heavy water plant..$^{8}$ The responses of NBEPC management and Premier Richard Hatfield were enthusiastic in light of a guaranteed market for one-third of the reactor's output and the estimated 1,875 construction jobs. ${ }^{39}$ Working closely with EMR officials, NBEPC submitted its application on 13 July 1973 in which it was argued that the federal government should provide loans to NBEPC to cover 75 per cent of the cost of the nuclear reactor in order to maintain acceptable debit-equity ratios for NBEPC..$^{\circ}$

EMR acted as the federal advocate for the NBEPC proposal, drafting a Memorandum to Cabinet in support of the NBEPC proposal on 13 July. While acknowledging that the New Brunswick site would rank fourth out of eight potential locations in terms of the costs of heavy water, EMR officials argued that a New Brunswick location would accelerate the introduction of nuclear power to the Maritimes and that "nuclear is essential in the Maritimes to prevent importing oil for electricity." ${ }^{41}$ AECL, in contrast, supported the

37 See A.R. Burge to A.J. O'Connor, 11 February 1972, file 3-333 Atomic 1972, NB Power Central Records for correspondence regarding nuclear opponents. For an example of the nuclear industry's tactical analysis of the environmental opposition, see "A Report on Nuclear Protest Groups and the Apparent Development of a Social Movement," 26 November 1975, file 87-00174, Ontario Hydro Central Records (Toronto).

38 J. Stewart Brooks, Chairman, NBEPC to Premier R. Hatfield, 22 March 1973, with attached "Meeting Notes of March 22, 1973 Prepared by John Foster, Vice-President, AECL Meeting between NBEPC officials and AECL," Hatfield Papers, RS 417, Atomic Energy 1973, PANB.

39 See "Heavy Water Plant Proposal New Brunswick Location," 6 April 1973, RS 417, NBEPC 1973, PANB for NBEPC's correspondence with the premier's office regarding the potential for 1,875 construction jobs and 350 permanent jobs.

40 "Nuclear Power Plant and Heavy Water Complex for New Brunswick," 6 July 1973, Lepreau Records, 87-00000, file 3, NB Power Central Records.

41 Memorandum to Cabinet "New Brunswick Proposal for Nuclear Generation and Heavy Water Production," 13 July 1973, Department of Finance Records, RG 19, vol. 5362, file 3954-L599-3, pt. 3, Lepreau Financing, LAC. 
lower-cost Quebec site to minimize its heavy water costs. ${ }^{42}$ Department of Finance officials maintained the position that any New Brunswick nuclear assistance should be deferred until the work of the ongoing Interdepartmental Working Group on Nuclear Power was completed, a key part of which was an evaluation of the economics of nuclear power in the Canadian context. ${ }^{43}$ The deputy minister of Finance also argued that a nuclear delay in New Brunswick would provide time to examine alternatives to NBEPC's nuclear path in the context of several federal national energy policy initiatives, including the extension of the national oil pipeline to the Maritimes, east-coast oil developments, and possible NBEPC imports from hydro developments in Quebec and on the Lower Churchill. ${ }^{44}$ On 21 September 1973, the general manager of NBEPC presented the New Brunswick case to the federal Cabinet at their meeting in Saint John, stressing NBEPC's commitment to nuclear power. ${ }^{45}$ By October 1973, however, the New Brunswick government had accepted the failure of its heavy-water nuclear proposal, as the federal government opted for the lower-cost site in Quebec. ${ }^{46}$

\section{Regional reactors $(2 \times 600)$, November 1973-March 1974}

With the failure of both their nuclear export strategy and the combined reactor/heavy water complex, NBEPC managers shifted their focus to the eastern Canadian market. Their most optimistic scenario was summarized in a 13 December 1973 nuclear progress report to the NBEPC Board of Commissioners in which the general manager outlined a hypothetical

42 Memorandum from S.S. Reisman to Minister MacDonald, Subject: Cabinet Agenda, Location for New Heavy Water Production Plant: New Brunswick Proposal for Nuclear Generation and Heavy Water Production, 18 July 1973, Department of Finance Records, RC 19, vol. 5362, file 3954-L599-3, pt. 3 Lepreau-Financing, LAC.

43 For the mandate of the working group, see Memorandum from I.A. Stewart to G.F. Osbaldeston, Subject: AECL, 7 May 1973, Dept. of Finance Records, RG 19, vol. 5358, file 3940-02, pt. 2, Nuclear Power-Study of Nuclear Power Program 1973, LAC. For the position of the Department of Finance, see Memorandum from G.F. Osbaldeston to C.M. Drury, 16 July 1973, Department of Finance Records, RG 19, vol. 5362, file 3954-L599-3, pt. 3 , Lepreau Financing, LAC.

44 Memorandum from S.S. Reisman to Minister MacDonald, 29 October 1973, Dept. of Finance Records, RC 19, vol. 5362, file 3954-L599-3, pt. 3, Lepreau Financing, LAC.

45 "New Brunswick's Electrical Energy Supply," 21 September 1973, Records of the Deputy Minister, Department of Regional Economic Expansion, file 116-A-13, Atlantic Power Development, LAC.

46 Memorandum from J. Austin to Minister MacDonald, Subject: New Brunswick Proposal for a Nuclear Project, 17 October 1973, EMR Records, X085-3, vol. 2, LAC and J. McNichols, Office of Minister D.S. MacDonald to Premier Hatfield, 7 December 1973, RS 417, Atomic Energy 1973, PANB. 
scenario involving two 600-megawatt regional nuclear reactors supplying Hydro-Québec (300 megawatts), Nova Scotia (350 megawatts), and Maine (50 megawatts). They assumed that the federal government could be convinced to provide 50 per cent of the financing for both units, Nova Scotia would take a 25 per cent equity position, and the Hydro-Québec sales would generate profits for NBEPC. The construction costs were not yet confirmed, but they assumed $\$ 448$ million for the first unit and $\$ 467$ million for the second with AECL guaranteeing the construction costs of the nuclear steam supply system. In spite of their recent lack of success, they presented their impending nuclear decision to the NBEPC Board as almost inevitable: "The target would be to be in a position to sign letters of intent, tie down financial agreements and be prepared to place equipment on order as early as possible - optimistically by early spring." ${ }^{47}$

This early optimism had already started to deteriorate in the three weeks prior to the presentation. NBEPC's financial advisor, First Boston, advised NBEPC in November 1973 that in order to maintain its financial stability with any nuclear program NBEPC would need risk guarantees on the plant operating performance, negotiated take-or-pay sales contracts, a federal government cap on construction costs, and another financial backer who would both provide and guarantee 50 per cent of the loans. ${ }^{48}$ None of these existed. In early discussions with EMR, the general manager of NBEPC had stressed loan guarantees with the federal government as NBEPC could be financially ruined if the reactor did not operate properly or was delayed. ${ }^{49}$ Additionally, the federal Department of Finance officials were adamant in their opposition to guaranteeing provincial loans and to the prospect of covering risks of construction overruns and poor operating performance of a provincial nuclear plant..$^{50}$ Furthermore, negotiations with Hydro-Québec were stalled over the selling price..$^{51}$ Negotiations with Nova Scotia had not gone beyond

47 Memorandum from A.J. O'Connor to NBEPC Board of Commissioners, 13 December 1973, Lepreau Records, 87-00000, file 3-422b N, folder 6 (5-8-E), NB Power Central Records.

48 Meeting Notes: Meeting in New York-First Boston, 22 November 1973, Lepreau Records, 87-00000, folder 6, NB Power Central Records.

49 Memorandum from G.M. MacNabb to Minister MacDonald, Subject: New Brunswick Nuclear Plant, 19 November 1973, EMR Records, X085-3, vol. 2, LAC.

50 Memorandum from T.K. Shoyama to S.S. Reisman, Subject: New Brunswick CANDU Reactor, 14 December 1973, Department of Finance Records, RG 19, vol. 5362, file 3954-3, pt. 3 Lepreau-Financing, LAC.

51 Memorandum from G.M. MacNabb to Minister MacDonald, Subject: New Brunswick Nuclear Station, 6 December 1973, EMR Records, X085-3, vol. 2, LAC. 
correspondence with the Nova Scotia premier, and it was expected that they would be difficult given Nova Scotia's interest in direct transmission access to the Hydro-Québec and New England markets through New Brunswick; direct transmission would have eroded NBEPC's export market potential..$^{52}$ In spite of these setbacks, NBEPC management persisted.

Officials of EMR prepared a Memorandum to Cabinet requesting special support beyond the federal policy established by Cabinet in November 1973 of providing loans for 50 per cent of the construction costs of the first nuclear reactor in each province. EMR officials recommended, given possible participation by Nova Scotia in the power station, that the 50 per cent federal loan should extend to a second reactor as well. Also, EMR recommended further considerations for NBEPC given the exceptional financial exposure from construction delays and operational problems..$^{53}$ Officials of the Department of Finance were strongly opposed to both proposals, arguing that any assistance for a second reactor should be under the mandate of the Department of Regional Economic Expansion (DREE) rather than EMR. ${ }^{54}$ The federal Cabinet decision of 17 January 1974 accepted EMR's recommendations for loans for two units (but with the second unit under DREE's mandate); stipulated that any further considerations were to be decided by an interdepartmental committee with representatives from Finance, EMR, AECL, and DREE; and required that there be a full evaluation of the economics of nuclear versus other sources of power in the New Brunswick case as suggested by Finance. ${ }^{55}$ The Cabinet decision of 17 January reflected

52 See J. Stewart Brooks Chairman NBEPC to Premier Richard Hatfield, 25 September 1974, RS 417, Nuclear Power 1974, PANB.

53 See Memorandum to Cabinet "New Brunswick Nuclear Power Station," 8 January 1974, Dept. of Finance Records, RG 19 4825/L599-4, vol. 1, Nuclear Power - Domestic Projects Lepreau I (New Brunswick), LAC.

54 Memorandum from S.S. Reisman to Minister MacDonald, Subject: New Brunswick Nuclear Power Station, Cabinet Document 32-74 for Consideration by Cabinet Committee on Government Operations, 9 January 1974, Department of Finance Records, RG 19, 4823/L599-4, vol. I, Nuclear Power-Domestic Projects Lepreau I (New Brunswick) Financing, LAC.

55 Memorandum from S.S. Reisman to Minister MacDonald, Subject: Canadian Nuclear Power Program Cabinet Document 24-74 for Consideration at Joint Meeting of Cabinet Committees on Federal-Provincial Relations and Economic Policy, 9 January 1974, Department of Finance Records, RG 19 4823/L599-4, vol. I, Nuclear Power-Domestic Projects Lepreau I (New Brunswick) Financing, LAC. 
the increasing importance of the departments of DREE and Finance in federal nuclear policy..$^{6}$

In the negotiations that followed, NBEPC continued to ask for risk coverage for construction cost overruns and poor operating performance of the reactors. This entailed significantly more federal assistance than HydroQuébec had received for the Gentilly II reactor, a federal loan for 50 per cent of a predetermined capital cost. The federal interdepartmental committee, with a strong Finance presence, was prepared to offer only a few incremental changes over the Hydro-Québec agreement: removing the cap on the federal loan, advancing federal loans on a regular basis to eliminate the need for NBEPC interim financing, and increasing the repayment period from 25 to 30 years. The federal interdepartmental committee would not agree to risk coverage of additional interest charges during construction due to any start-up delays and coverage of poor operating performance..$^{57}$ Finance officials had not altered their view that NBEPC, because of its small size, did not have the financial capacity to handle the risk of a nuclear plant, and that there was no evidence that nuclear power was a rational economic choice for New Brunswick given the possibilities of thermal generation and Hydro-Québec imports..$^{5}$ However, well in advance of the final federal decision, NBEPC decided in March to commit to the nuclear project without a federal agreement.

\section{Going it alone with nuclear power}

On 19 March 1974, in an eight-page presentation for the Board of Commissioners of NBEPC titled "Nuclear Power for New Brunswick in 1980," the executive director of NBEPC's Nuclear Power Program presented the

56 Privy Council Office, Record of Cabinet Decision, No. 24-74D, Canadian Nuclear Power Programme, 17 January 1974, EMR Records, X085-3, Energy \& Power-NuclearNew Brunswick Nuclear Power Station, LAC. For the perspective of Finance officials, see Memorandum from T.K. Shoyama to Mr. S.S. Reisman, Subject: Nuclear Power Memoranda: Discussion in Cabinet Committee on Government Operations, 17 January 1974, Department of Finance Records, RG 19, 4823/L599-4, vol. I, Nuclear Power-Domestic Projects Lepreau I (New Brunswick), LAC.

57 Memorandum to Cabinet "Financing by the Federal Government of a Nuclear Power Station in New Brunswick," 24 April 1974, Department of Finance Records, RG 19, 4823/ L599-4, vol. 1, Nuclear Power-Domestic Projects Lepreau I (New Brunswick), LAC.

58 For the reservations of the Finance Department's analysts, see Memorandum from Allan Blair to Myles B. Foster, Subject: AECL/NBEPC Nuclear Station, 14 February 1974 and Memorandum from R.A. Fleming to File, Subject: Meeting February 14, 1974 Financing of New Brunswick Nuclear Station, 15 February 1974, both in Department of Finance Records, RG 19, 4823/L599-4, vol. 1, Nuclear Power-Domestic Projects Lepreau I (New Brunswick) Financing, LAC. 
argument for NBEPC proceeding with a one-unit nuclear project on its own. 59 The possible benefits of a quick nuclear decision were, according to the report, to avoid additional dependence on the international oil market, preserve their all-nuclear scenario, and avoid delays and increasing prices for the increasingly expensive nuclear components. The possible costs were identified as the risks of not getting participation agreements and the associated necessity to purchase or build expensive reserve capacity in the event of the unit going out of service. The submission to the Board of Commissioners made no reference to the risks of potential capital cost overruns, project delays, and poor operating performance, which were the substance of their negotiations with the federal government. Utilizing analysis provided by Montreal Engineering, the report claimed that nuclear power was the lowest-cost alternative for NBEPC. ${ }^{60}$ It also stated that NBEPC would be able to borrow its 50 per cent share of the construction costs. The report recommended that the NBEPC Board approve what it referred to as the "go it alone scenario," a 600-megawatt unit for a 1980 start-up date while continuing discussions with regional utilities for possible participation. With the general manager supporting the nuclear decision, NBEPC's Board of Commissioners officially approved the nuclear reactor project on 20 March $1974 .{ }^{61}$

\section{The federal conditions for the loan}

On 2 May1974 the federal Cabinet approved a loan to New Brunswick for 50 per cent of the reactor costs for both a provincial reactor and a future second regional unit at the same site, but with a cap on the loan and several preconditions that would need to be met before the loan could be finalized. ${ }^{62}$ In earlier discussions, there was no cap on the loan based on the assumption that AECL would provide a fixed-price contract for the nuclear steam supply system of the reactor. However, NBEPC managers were having little success

59 F.H. Ryder, "Nuclear Power for New Brunswick in 1980," 13 March 1974, Lepreau Records, 87-00002 (5-8-E), NB Power Central Records.

60 "The New Brunswick Electric Power Commission Assessment of Generation Alternatives for the Period 1980-82," prepared by Montreal Engineering Company Limited, 7 March 1974, RS 417, Nuclear Power 1974, PANB. Montreal Engineering, an engineering services company, provided a range of financial and project-evaluation services to NBEPC in the 1970s.

61 Board of Commission Minutes of 19 and 20 March 1974, NB Power Central Records.

62 Record of Cabinet Decision, meeting of 2 May 1974 (280-74RD), Financing by the Federal Government of Nuclear Power Station in New Brunswick, 2 May 1974, EMR Records, X085-2-1, LAC. 
in having AECL commit to a fixed-price contract, and when they finally provided it in March 1974 it was on a cost-plus basis and considerably above the often-quoted figure of $\$ 488$ million. NBEPC believed the AECL costs were inflated and "not a sound basis for a lump sum contract or for that matter any other type of contract." ${ }^{33}$ Subsequently, NBEPC chose to take on the risk of self-management of construction of both the nuclear and conventional parts of the reactor project. ${ }^{64}$ The federal Cabinet, in response to the arguments of the Department of Finance, decided to cap the 50 per cent federal loan, as they were not willing to accept the added risk of increased construction costs due to NBEPC's managing the construction. ${ }^{65}$ Additional terms and conditions of the Cabinet decision were that the federal departments of DREE, the Department of Environment, and the AECB must approve the site, and that NBEPC must submit for approval of the federal government, prior to the arrangements for financing, "an evaluation of the economics and associated financial risks of the project, including a summary of cost estimates and commercial financing." 66

\section{Conflict over regional policy}

NBEPC managers, and their allies among EMR and AECL officials, attempted to avoid the preconditions for federal involvement in site selection, environmental review, and evaluation of the economic viability of the nuclear project. NBEPC's export-led strategy, for instance, had, since the late 1960 ,

63 Notes of Meeting with AECL-March 13, 1974, 14 March 1974, Lepreau Records, 87-00000, folder 7, NB Power Central Records. R.H. Ryder concluded from the meeting that AECL planned to charge cost plus $90 \%$ on engineering costs of the NSSS. The next day, at a meeting of NBEPC's Executive Committee, they decided that they could build the reactor at a lower cost than any turnkey contract with AECL. See Minutes of Meeting of Executive Committee, 14 May 1974, Lepreau Records, 87-00000, folder 7, NB Power Central Records.

64 See J. Stewart Brooks, Chairman, NBEPC to Dr. J.L. Gray, President, AECL, 29 March 1974, Lepreau Records, 87-00000, folder 7, NB Power Central Records and Memorandum from G.H.D. Ganong, Manager of Design and Construction to A.J. O'Connor, General Manager, 1 April 1974, Lepreau Records, 87-00000, folder 7, NB Power Central Records.

65 Memorandum from S.S. Reisman to Minister of Finance, Subject: Financing by the Federal Government of Nuclear Power Station in New Brunswick, 2 May 1974, Department of Finance Records, RG 19, 4823/L599-4, vol. 1, LAC. EMR officials, as well, had assumed NBEPC would sign a turnkey contract with AECL for the nuclear steam supply system (NSSS), the high-risk component of the project. See F.C. Boyd to G.M. MacNabb, "Note to File, New Brunswick Nuclear Power Station," 21 May 1974, EMR Records, X085-3, Energy \& Power-Nuclear-New Brunswick Nuclear Power Station, LAC.

66 Record of Cabinet Decision, Meeting of 2 May 1974 (280-74D), Financing by the Federal Government of Nuclear Power Station in New Brunswick, 2 May 1974, EMR Records, X085-2-1, LAC. The federal conditions on the proposed federal assistance can also be found in Minister MacDonald to Premier Hatfield, 10 June 1974, RS 417, 5243-0, 1987 Policy, PANB. 
created conflicts with federal policies encouraging regional cooperation, especially over joint transmission access and generation planning. ${ }^{67}$ Added to the federal concern with rationalizing the Maritime electrical utility sector was the increasing importance of uneven regional development in the early $1970{ }^{68}{ }^{68}$ Such was the importance of federal regional development objectives that EMR Minister Donald S. MacDonald was convinced, in March 1974, by the New Brunswick minister in the federal Cabinet, Jean-Eudes Dubé, that a northern New Brunswick site would be superior to NBEPC's planned southern site. MacDonald instructed his deputy minister in March to keep New Brunswick MPs Jean-Eudes Dubé and Herb Breau informed of the progress on the file. ${ }^{69}$ The officials in the nuclear unit within EMR were disturbed by this challenge to their traditional authority, especially as NBEPC in April was already placing orders and negotiating engineering contracts based on a southern site..$^{70}$ Their fears were not unfounded: a Cabinet decision on 2 May gave DREE a veto over the site selection for the first reactor site on the grounds that the site chosen would also become the site for the second reactor.

DREE regional staff began their socioeconomic research in June; on 15 July they recommended to their minister that, from an economic development perspective, the project should be located in the north of the province at one of two sites NBEPC had previously considered and that DREE should provide assistance for related infrastructure and training costs. ${ }^{71}$ Three days later, Premier Hatfield officially announced the choice of Lepreau in southern New Brunswick. His supporting documentation stated that the southern site was $\$ 30$

67 See Andrew G. Secord, "NB Power 1967-72: Constructing the Export Dream," Journal of New Brunswick Studies 10 (Fall 2018): 10-12.

68 For an historical overview of regional policy in Canada, see Janine Brodie, The Political Economy of Canadian Regionalism (Toronto: Harcourt Brace Jovanovich, 1990), 168-75, 204-15. For its importance at the federal level in the early 1970s, see James Bickerton and Alain G. Gagnon, "Regional Policy in Historical Perspective: The Federal Role in Regional Economic Development," American Review of Canadian Studies 14, no. 1 (1984): 77-82 and Clyde Weaver and Thomas I. Gunton, "From Drought Assistance to Megaprojects: Fifty Years of Regional Theory and Policy in Canada," Canadian Journal of Regional Science V, no. 1 (Spring 1982): 13-14.

69 Minister Donald S. MacDonald to Deputy Minister, Proposed Siting of the New Brunswick Nuclear Plant, 12 March 1974, EMR Records, X085-3, Energy \& Power-Nuclear-New Brunswick Nuclear Power Station, LAC.

70 Memorandum from F.C. Boyd to G.M. MacNabb, Subject: Points re New Brunswick Power Plant for Discussions with DREE Officials, 9 April 1974, EMR Records, X085-3, Energy \& Power-Nuclear-New Brunswick Nuclear Power Station, LAC.

71 Memorandum from J.P. Francis, Acting Deputy Minister, DREE to Minister Jamieson, Subject: New Brunswick Nuclear Plant-Selection of Site, 15 July 1974, Records of the Deputy Minister of DREE, file 116-A-13, LAC. 
million less expensive than a northern site, and could be completed sooner. ${ }^{72}$ Hatfield was unequivocal in his support of the NBEPC recommendation that the choice of site should be based on minimizing NBEPC's costs. Over the summer, DREE officials continued their research into the value of the northern sites while federal Cabinet support for a northern site increased. The prime minister's office instructed the nuclear energy division within EMR to provide information on locations other than Lepreau, ${ }^{73}$ and EMR Minister MacDonald informed Premier Hatfield that DREE would be evaluating all three project sites for their economic and employment impact. ${ }^{74}$ MacDonald also informed the minister of Environment that three sites were still under consideration by DREE, and he recommended that the Department of Environment should not restrict its reviews to the one southern site. ${ }^{75}$ DREE staff submitted their assessment of the three sites to their minister on 25 September, arguing that the socioeconomic benefits of a northern site exceeded any additional costs NBEPC might incur - costs for which DREE staff suggested compensation. The deputy minister stressed the value of direct job creation in one of the most economically depressed regions in the country. It was suggested that the socioeconomic advantage of a northern site would be upwards of $\$ 40$ million. ${ }^{6}$

The nuclear unit within EMR, however, produced research for the minister of EMR in support of NBEPC's southern site. Based on the engineering and cost data provided by NBEPC, EMR officials stressed that a northern location would cost an additional \$35 million plus a one-year delay in order to study cooling water issues at the northern site. Such delays would generate additional

72 For the complete press package with supporting documentation, see "Energy Planning for New Brunswick," 18 July 1974, RS 917, Records of the Deputy Minister of Finance 1974, Provincial Finance, Financing NB Power, PANB. The rationale for the nuclear decision is included as "Decade of Progress 1970-1980 Strategy Towards Oil Substitution and System Security."

73 George Post, Acting Deputy Secretary to the Cabinet to Dr. O.J.C. Runnals, Senior Advisor, Uranium and Nuclear Energy, EMR, 12 August 1974, EMR Records, X085-2-3-1, LAC.

74 Minister Donald S. MacDonald to Premier Richard Hatfield, 27 August 1974, RS 417, 5243-0, 1987 Policy, PANB.

75 John McNicholas, Executive Assistant to Minister MacDonald, to Roméo Beaupre, Executive Assistant to Minister of Environment, 10 September 1974, EMR Records, EMR X085-1, LAC. The letter also refers to the meetings among ministers MacDonald, Jamieson, and LeBlanc, who all supported this position.

76 Memorandum from J.D. Love, Deputy Minister, DREE to Minister Jamieson, Subject: New Brunswick Nuclear Plant-Site Selection, with attached study "Socio-Economic Aspects of the Site Selection Decision for the Nuclear Power Station in New Brunswick," 25 September 1974, Records of the Deputy Minister of DREE, file 116-A-13, LAC. 
costs for financing and replacement power.77 For NBEPC managers, delays and added costs for a northern site would cause fundamental problems for what was an increasingly costly and risky nuclear option. In a September briefing note to Premier Hatfield, the manager of NBEPC stated his position that "the only site that permits an all-nuclear expansion is the Pt. Lepreau site and then ONLY if we proceed on a continuous uninterrupted manner with the work." 78

The conflict over the site was resolved in meetings in Ottawa on 18 and 19 September and a final meeting on 7 October. ${ }^{79}$ The September meetings, with federal minsters Don Jamieson (DREE), Donald MacDonald (EMR), and Roméo LeBlanc (Fisheries), and Premier Hatfield, along with Arthur J. O'Connor, general manager of NBEPC, set out positions but produced no agreement. ${ }^{80}$ The general manager of NBEPC steadfastly refused to consider a northern site. EMR Minister MacDonald supported DREE's focus on a site to meet federal regional development objectives; and Minister LeBlanc was specifically committed to the regional development agenda for the north of the province. ${ }^{81}$ The 7 October's morning meeting consisted of officials of DREE, NBEPC, and EMR trying to reach agreement on the socioeconomic implications of the sites. Officials of EMR and NBEPC agreed that the extra costs to NBEPC of a northern site were in the range of $\$ 47-100$ million, while DREE officials provided their much lower estimates. One of the attending EMR officials described the meeting as mostly arguments between DREE and NBEPC officials - "Two hours of occasional slightly heated exchanges without any sign of consensus." ${ }^{82}$ In the afternoon, Hatfield, along with the general manager of NBEPC, met with federal ministers MacDonald, Jamieson, and

77 Memorandum from G.M. MacNabb to Minister MacDonald, Subject: Siting of the New Brunswick Nuclear Power Project, with attached report "Review and Assessment of the Selection of the Point Lepreau Site for a Nuclear Power Station in New Brunswick," 9 September 1974, EMR Records, file X085-2-1, LAC and F.C. MacLoon, Manager of Production and Planning, NBEPC to F.C. Boyd, Assistant Advisor-Nuclear Energy, 29 July 1974, EMR Records, file X086-30/4-1, LAC.

78 A.J. O'Connor, General Manager, NBEPC to Premier Richard B. Hatfield, handwritten notes (6 pages), September 1974, Hatfield Papers, RS 417, Nuclear Power 1974, PANB.

79 Memorandum from A.R. Scott to G.M. MacNabb, Senior Deputy Minister, EMR, 10 October 1974, EMR Records, file X085-2-1, LAC.

80 Roméo LeBlanc was appointed Minister of State for Fisheries on 8 August, replacing Jean-Eudes Dubé as the New Brunswick minister in the federal Cabinet.

81 See "Notes on Ottawa Meetings," 18, 19 September 1974, Lepreau Records, 87-00000, file 7 (5-8-G-a), NB Power Central Records.

82 Memorandum from A.R. Scott to G.M. MacNabb, Senior Assistant Deputy Minister, Subject: New Brunswick Nuclear Station, 10 October 1974, EMR Records, file X085-2-12, LAC. 
LeBlanc but had no more success than their officials in reaching an agreement. In an interview with this author, Premier Hatfield commented: "Those negotiations were the worst I ever had. I mean it was at the point of anger. The discussion was at the point of shouting at each other." ${ }^{83}$ In lieu of withdrawing the provision of federal loans for the project, the federal ministers agreed to continue with loans for the first unit but to withdraw financing for a second regional unit should it be pursued in the future. As for NBEPC, they gave up federal assistance for what they considered an inevitable second nuclear reactor in exchange for maintaining their autonomy in corporate decision-making.

\section{The environmental review process}

The location of the reactor resolved, NBEPC managers turned their attention to gaining approval from the federal Department of Environment in the context of the federal Environmental Assessment and Review Process (EARP); this procedure was introduced by Cabinet for all federal agencies in December 1973. The Cabinet directive stated that the review was to occur before "irrevocable decisions" had been taken and that environmental problems should be given "the same degree of consideration as that given economic, social, engineering and other concerns." ${ }^{84}$ Reviews were to be carried out by a projectspecific Environmental Assessment and Review Panel (EA Panel) consisting primarily of federal government officials, including a representative from the initiating department; this type of self-assessment was "intended to diffuse environmental responsibility throughout Government." ${ }_{5}$

At a meeting on 21 May 1974, EMR officials informed NBEPC's general manager that the nuclear project would require Department of Environment approval through the federal EARP process. According to meeting notes, the general manager expressed "grave concern" as the process could lead to a 12 -month delay. ${ }^{86}$ Once the official guidelines for a comprehensive

83 Premier Richard B. Hatfield, interview by Andrew G. Secord, 3 July 1990, Fredericton, transcript, MC 1677, PANB.

84 The Cabinet meeting of 20 December 1973 confirmed the recommendation of the Cabinet Committee on Science, Culture, and Information; see Environmental Assessment and Review Process, 20 December 1973, EMR Records, file X-085-2-1, LAC.

85 Robert Gibson has extensively analyzed the evolution of environmental assessment in Canada, including this early phase of self-assessment; see Robert B. Gibson, "From Wreck Cove to Voisey's Bay: The Evolution of Federal Environmental Assessment in Canada," Impact Assessment and Project Appraisal 20, no. 3 (September 2002): 151-9.

86 F.C. Boyd to G.M. MacNabb, "Note to File-New Brunswick Nuclear Power Station," 21 May 1974, Records of the Minister of EMR, file X085-3, Energy \& Power-NuclearNew Brunswick Nuclear Power Station, LAC. For details of NBEPC's response, see 
environmental review were available, EMR officials arranged a 4 November 1974 meeting with officials from NBEPC, EMR, and the chair of the EA Panel, Dr. R.R. Logie. According to EMR's staff meeting notes, NBEPC indicated that they were already proceeding with the project and did not intend to stop for the EARP process. Acquiescing to NBEPC's pressure, the EA Panel agreed to postpone the one-year comprehensive assessment and require only a preliminary assessment that NBEPC's consultants said they could complete in four weeks. The revised guidelines for a preliminary environmental review were approved four days later. In a letter from Dr. Logie to EMR's member of the EA Panel, it was pointed out that the minister of Environment was "very unhappy with the notion of having to give environmental approval on the basis of incomplete environmental information." ${ }^{87}$ In spite of the minister's reservations, the process went ahead, and McLaren Atlantic submitted their "Preliminary Environmental Impact Statement" to NBEPC on 4 February 1975. DOE released the study to the public on 6 March, and allocated one day for public responses on 3 April in Saint John.

The participants at the Saint John meeting were opposed to the nuclear reactor by a 5-to-1 ratio, with many challenging the legitimacy of the process, the justification for the reactor, the economic viability of nuclear power, the adequacy of the preliminary study as a basis for environmental approval, and/or the problem of the radioactive wastes (especially plutonium with a half-life of 24,000 years). Almost every component of the McLaren study was challenged, ${ }^{88}$ reflecting the capacity of the opposition to nuclear power in New Brunswick ${ }^{89}$ that had been coalescing into the Maritime Coalition of Environmental Protection Associations since the first rumours of building

Memorandum from F.C. Boyd to G.M. MacNabb, Subject: New Brunswick Nuclear Power Plant Environmental Assessment, 24 May 1974, EMR Records, file X085-2-1, LAC.

87 Letter from R.R. Logie, Environment Canada to F.C. Boyd, Assistant Advisor on Nuclear Energy, EMR, 10 December 1974, EMR Records, file X085-2-1, LAC. It is unclear, based on available documentary evidence, why the minister did not take a stronger position, especially given the strength of the Cabinet directive.

88 Proceedings of the Public Meeting on the Preliminary Environmental Impact Statement Lepreau Nuclear Generating Station, 3 April 1975. Prepared by the Saint John River Basin Board Public Participation Section, Government Documents, Harriet Irving Library, University of New Brunswick, Fredericton. The document includes both a verbatim transcript and copies of the 40 written briefs that were submitted to the panel.

89 A report for Ontario Hydro and shared with NBEPC, identified 48 anti-nuclear groups in the Maritimes and 35 in Ontario based on their consultants' "informally participating" and collecting "personal information" to identify number of members, revenues, and activities; see "A Report on Nuclear Protest Groups and the Apparent Development of a Social Movement," Public Attitude Research Department, Ontario Hydro (File 87-00174), 26 November 1975, Lepreau Records, 87-00000, NB Power Central Records. 
nuclear reactors for export to the United States in $1971.9^{\circ 0}$ Although part of the scope of the preliminary assessment, the EA Panel did not address any of the public's arguments challenging the economics and need for the nuclear reactor. Instead, they forwarded a list of eight question areas to the nuclear unit at EMR for responses. The assessment panel did not utilize any independent expertise and instead relied entirely on responses from EMR, which had been constructed with assistance from AECL and AECB..$^{11}$

The EA Panel's report was submitted to the minister on 2 May. ${ }^{92}$ On 7 July 1975, Minister Sauvé forwarded the conclusions of the EARP process to Minister MacDonald. Aside from a few requirements for environmental monitoring, the principal recommendation was that "a national policy for the storage, disposal, and reprocessing of radioactive waste be developed as soon as possible." In Sauvé's opinion, “I believe we came jointly to a good conclusion in this environmental assessment but it will be of course meaningless if the recommendations are not followed through." 93 On 20 August, Minister MacDonald responded to Minister Sauvé's letter, indicating that they would leave the issue of high-level radioactive waste to the Atomic Energy Control Board, which intended to set up a committee to look at the problem. ${ }^{94}$ In his evaluation of the environmental assessment process in Canada in the 1970s, D. Paul Emond, of the Osgoode Hall Law School, wrote: "As far as Point Lepreau was concerned, EARP was clearly an empty and meaningless exercise."95

90 For a listing of the associations challenging the nuclear project, see Maritime Coalition of Environmental Protection Associations, Nuclear Reaction: The Maritime Voice Against Nuclear Power (Fredericton: Maritime Coalition of Environmental Protection Associations, Summer 1975), p. 4. The issues of Nuclear Reaction can be found in MC 326, MS6B1, Nuclear Reaction Issues, PANB.

91 Letter from F.C. Boyd to Dr. R.R. Logie, Chairman, Canadian Environmental Advisory Council, "Point Lepreau Generating Station Questions from the Public," 28 April 1975, EMR Records, file X085-2-1, LAC.

92 "Report to: The Minister of the Environment from: The Environmental Assessment Panel, Point Lepreau New Brunswick Nuclear Generation Station," 2 May 1975, DREE Records, file 116-A-13, LAC.

93 Letter from Jeanne Sauvé, Minister, Department of Environment to D.S. MacDonald, Minister, Department of Energy, Mines and Resources, 7 July 1974, EMR Records, file X085-2-1, LAC.

94 Letter from Minister Donald S. MacDonald to Minister Jeanne Sauvé, 20 August 1975, EMR Records, file X085-2-1, LAC.

95 D. Paul Emond, Environmental Assessment Law in Canada (Toronto: EdmondMontgomery, 1978): 250. 


\section{Economic and financial review}

The last prerequisite proved the most difficult for NBEPC: providing evidence of the economic and financial viability of the nuclear project. NBEPC's Board of Commissioners based their decision in March 1974 on an analysis prepared by Montreal Engineering. As discussed previously, they did not address the financial risks associated with construction delays, construction costs overruns, and unplanned outages - all risks that NBEPC management had unsuccessfully tried to reduce through federal coverage ${ }^{96}$ Financial analysis was reduced to a statement by First Boston Corporation, their fiscal agent, that the required loans would not exceed the borrowing capacity of New Brunswick. ${ }^{97}$ Officials with the federal Department of Finance required a much more rigorous analysis.

EMR initiated a meeting in Ottawa on 20 June 1974 with officials of AECB, DOE, DREE, and NBEPC to "review, for mutual benefit, the requirements, procedures and status of approval by each of three agencies." ${ }^{98}$ While most of the time was spent providing guidance to NBEPC on dealing with DREE and DOE, EMR staff also advised NBEPC executives on the required economic and financial evaluation of the project. Frank Ryder of NBEPC recorded in his meeting notes that the assistant deputy minister of EMR stressed (based on analysis by the Organization for Economic Cooperation and Development) that oil prices would rise until 1978 and then "drop drastically as a result of overcapacity," 99 effectively undermining NBEPC's economic analysis as provided by Montreal Engineering. In response, EMR staff advised NBEPC to shift their argument to the security of supply issue rather than the price of oil, ${ }^{100}$ an argument that found little support in the federal Department of Finance given the availability of western Canadian oil and the potential for a national pipeline.

96 For EMR's identification of these limitations, see Memorandum from F.C. Boyd to G.M. MacNabb, Subject: New Brunswick Nuclear Power Plant Meeting with NBEPC, Fredericton, 26 July 1974, EMR Records, X086-30/4-1, LAC.

97 Letter from Edward Townsend, Senior Vice President, First Boston Corporation to A.J. O'Connor, 4 September 1974, RS 417, Nuclear Power 1974, PANB.

98 Memorandum from F.C. Boyd to G.M. MacNabb, Subject: New Brunswick Nuclear Power Plant Approval of Site, 21 June 1974, EMR Records, file X085-2-3-1, LAC.

99 F.H. Ryder, Notes of meeting with Department of Energy, Mines and Resources, 20 June 1974, Lepreau Records, 87-00000, folder 7, NB Power Central Records.

100 F. MacLoon, Notes of meeting with Department of Energy, Mines and Resources, 20 June 1974 Lepreau Records, 87-00000, folder 7, NB Power Central Records. 
NBEPC resubmitted its economic and financial analysis to EMR on 21 August, ${ }^{101}$ and F. Boyd, Assistant Advisor, Nuclear Energy at EMR forwarded the work to E.T. Houston of their financial section for his evaluation of the adequacy of NBEPC's submission. Houston responded that the NBEPC analysis was inadequate as an evaluation of the economics and financial risks of the nuclear project. Specifically, the analysis had not examined the sensitivity of the results to a number of factors including capital cost overruns, higher interest rates, and lower capacity utilization rates - all factors that would increase the risks associated with the more capital-intensive nuclear choice. ${ }^{102}$

Officials at the Department of Finance also examined the adequacy of NBEPC's August 1974 economic and financial justification of the project. Trent Gow, Chief of General Economic Studies in the Economic Development Division, pointed out that NBEPC did not consider sources of power from outside the province and the economic costs of foregoing such purchases. His assessment was that NBEPC provided an engineering/financial review with some limited sensitivity analysis, but that it was not an economic evaluation or complete financial risk analysis. Much more would need to be done to include "a range of cost overruns, delays and combinations identifying decision 'crossover' points" and a "comprehensive assessment of the feasibility of such project-reversing occurrences." ${ }^{103}$ In September 1974 NBEPC management acknowledged that they had no confidence in the $\$ 499$ million capital cost estimate they had used in the August economic analysis, but it was not until 30 January 1975 that NBEPC officially revealed its $\$ 700$ million capital cost estimate at a joint meeting with AECL, EMR, and Finance officials.

In response to the higher estimate, both EMR and Finance officials concluded that the economic and financial analysis would have to be redone. ${ }^{104}$ In spite of several requests by EMR for NBEPC to do a revised economic

101 Letter from F.C. MacLoon, Manager of Production and Planning, NBEPC to F.C. Boyd, Assistant Advisor, Nuclear Energy, EMR, 21 August 1974, Dept. of Finance Records, RC 19, 4825/L599-4, vol. 2, Nuclear Power-Domestic Projects Lepreau I (New Brunswick) Financing, LAC.

102 Memorandum from E.T. Houston to F.C. Boyd, Subject: New Brunswick Nuclear Power Plant, August 1974, Dept. of Finance Records, RG 19, file 4825/L599-4, vol. 2, Nuclear Power-Domestic Projects Lepreau I (New Brunswick) Financing, LAC.

103 Memorandum from Trent Gow to R.N. Spalding, Subject: New Brunswick Nuclear, 25 Sept 1974, Dept. of Finance Records, RG 19, 4825/L599-4, vol. 2, Nuclear Power-Domestic Projects Lepreau I (New Brunswick) Financing, LAC (quotations on p. 2).

104 Memorandum from R.N. Spalding to Myles B. Foster, Department of Finance, Subject: AECL/NBEPC Financing Agreement, 3 February 1975, Department of Finance Records, RC 19, 4825/L599-4, vol. 5, LAC. 
analysis, nothing was submitted to EMR until 28 April, in the form of a slight modification to the August 1974 submission. Boyd at EMR had previously, on 10 April, asked T. Tuschak, Senior Advisor in their financial section, to comment (hopefully affirmatively for the project) on the implications of the new $\$ 700$ million capital cost. ${ }^{105}$ However, Tuschak reported to Boyd on 29 May that the issues he had raised in August 1974 to NBEPC's submission still had not been addressed - namely, the inadequacy of the commercial financing submission and the need for a complete sensitivity analysis. In his view, the economic and financial analysis was inadequate. Given the current $\$ 700$ million capital cost estimate, Tuschak commented that "the nuclear choice if it was to be made today is not that clear cut." ${ }^{106}$ Finance officials were even more critical, not only raising the issue of the poor methodology of NBEPC's work but also pointing out the "serious omission" of the April 1975 submission in omitting sensitivity analysis for interest rates, capital costs, delays, and operating equipment failures. The latest NBEPC report provided even less sensitivity analysis than the inadequate August 1974 one. Finance officials also pointed out that the incorrect costing of spinning reserves would, if done properly, shift the cost advantage from nuclear to oil. ${ }^{107}$

In spite of what Finance considered to be the lack of an adequate economic and financial analysis, the federal loan for the NBEPC nuclear project was approved by Treasury Board on 24 July 1975 as a financing agreement between AECL and NBEPC. The decision indicated that "Treasury Board discretion was virtually nil" given that federal support was public, AECB had given a construction licence, and AECL and NBEPC had issued contracts. The issues that Finance had been raising since January 1974 were not addressed. ${ }^{108}$ In the

105 Memorandum from F.C. Boyd to T. Tuschak, Subject: New Brunswick Nuclear Power Plant-Economic Evaluation, 10 April 1975, EMR Records, file X085-2-1, LAC. The memorandum indicates that EMR officials had asked NBEPC to update their analysis for the higher capital cost, but nothing was provided to EMR.

106 Memorandum from T.S. Tuschak to F.C. Boyd, Subject: New Brunswick Nuclear Power Plant, 29 May 1975, Department of Finance Records, file 4825-L599-4, vol. 4. LAC. In a hand-written note attached to a 15 May 1975 memo from Gore to Gow, Gore refers to EMR's Houston's view that "the consultant's report is a pretty shoddy job."

107 Their additional methodological concerns and identification of specific omissions are described in two memos from G.E. Gore to Trent Gow, Subject: Consultants Reports on Nuclear versus Alternative Generation Methods in New Brunswick (1980-82), 15 May and 21 May 1975, Department of Finance Records, RG 19, file 4825/L599-1, LAC.

108 Treasury Board Submission TB 737879EMR, Subject: Authority for the Financing Agreement Between Atomic Energy of Canada Limited (AECL) and New Brunswick Electric Power Commission (NBEPC) re. Nuclear Power Plant, 21 July 1975, EMR Records, file X085-2-1, LAC. For confirmation of the Treasury Board decision on 24 July, see Letter 
final memorandum to Treasury Board, it was left to AECL (not Finance or EMR) to state that, in its opinion, the economic and financial prerequisites were met. ${ }^{109}$ If NBEPC's strategy was to avoid revealing the poor economics of the project by delay, it was successful as the long process of obfuscation extended to the point where the federal government accepted that the project was too far advanced to hold up federal funding due to lack of proper economic and financial analysis. In spite of the power of the federal Department of Finance, the federal government had failed to bring serious economic and financial analysis to the case of the New Brunswick reactor.

\section{Conclusion}

NBEPC managers began in the late 1960 s to create conditions for transitioning to nuclear power generation in the 1970s, in the process committing to a path they were unwilling to abandon. They directed their corporate investments to high-voltage transmission interconnections with New England, which was a necessary condition for their all-nuclear strategy. When, in 1972, New England utilities rejected nuclear purchases from New Brunswick, NBEPC's exportled nuclear strategy had effectively failed. At this point, however, NBEPC managers continued along the nuclear path, exhibiting higher risk behaviour in the process. Both individually and as an organization, they continued as enthusiastic supporters of AECL's CANDU technology. Consistent with Helga Drummond's analysis of a "lock-in" psychology, as NBEPC executives spent more time and resources on the nuclear option, their personal attachment and the associated institutional commitment increased. In their original discussions with the federal government in 1971, NBEPC managers were adamant that they would not go forward with nuclear unless it was no more expensive (or risky) than a conventional oil-fired generator. However, between 1971 and 1974, NBEPC managers were willing to take on increasing levels of economic and financial risk, to the point where they were willing to proceed without sales participation agreements, without federal coverage for unforeseen construction cost increases and poor operating performance, and without a federal guarantee on the federal loan. In 1975, in response to a near-doubling of the capital cost estimate, they responded by taking on the uncertainties

from R.L. Richardson, Assistant Secretary, Treasury Board to J.S. Foster, President, AECL, 31 July 1975, Department of Finance Records, RG 19, file 4825-L599-4, vol. 4, LAC.

109 See Treasury Board Submission, 21 July 1975 in Department of Finance Records, RG 19, file 4825-L599-4, vol. 4, LAC and handwritten comment by Finance official on their copy of the Treasury Board submission: "AECL has left government no option but to approve it." 
of self-management of the construction of the nuclear steam supply system. At each step of the way, NBEPC managers, between 1972 and 1974, took on additional risk as costs increased and potential partners could not be found.

While investing in the physical infrastructure for nuclear exports, NBEPC officials also developed a social network with officials at EMR and AECL who had a shared interest in the promotion of nuclear power and were prepared to act in opposition to other officials in the federal departments of Finance, Environment, and Treasury Board Secretariat. Federal officials within the network provided assistance to NBEPC in writing proposals to federal ministers, developing common positions, sharing background information in advance of negotiations, and recommending tactics for dealing with other federal agencies as well as arguing the NBEPC case before Cabinet committees. This cross-government network of interests was especially active as NBEPC confronted the federal Cabinet on the location, environmental assessment, and economic appraisal of the nuclear project. With the collaboration of EMR and AECL officials, NBEPC managers were able to counter the federal Cabinet initiative to locate the reactor in the north for economic development purposes, undermine the environmental assessment process, and avoid a federal economic appraisal.

An adequate explanation for why a nuclear reactor was built in the midst of the communities of Maces Bay, Dipper Harbour, and Chance Harbour requires much more than a reference to ahistorical statistics such as the temperature of cooling water in the Bay of Fundy or the international price of oil. In this case, social networks built up over several years, although invisible to outsiders, were an essential component of the capacity of NBEPC executives to continue locked-in on the nuclear path to the bewilderment of both officials of the federal Department of Finance and the people of the Lepreau communities.

Andrew G. Secord est professeur agrégé d'économie à I'Université St. Thomas. Ses travaux de recherche actuels portent sur l'économie politique de l'énergie et de l'environnement au Nouveau-Brunswick.

Andrew G. Secord is an associate professor of economics at St. Thomas University. His current research focuses on the political economy of energy and environment in New Brunswick. 